\title{
Diagnosis in diabetes: does it matter?
}

\author{
${ }^{1}$ I Thethy, ${ }^{2} \mathrm{~L}$ Robertson, ${ }^{3} \mathrm{~K}$ Swaminathan \\ ${ }^{1}$ Specialist Registrar in Medicine, Department of Medicine; 'Diabetes Specialist Nurse; Consultant Endocrinologist, Department of Diabetes, \\ Victoria Hospital, Kirkcaldy, Fife, UK
}

\begin{abstract}
The diagnosis of diabetes subtypes in a busy clinic is usually based on the age at onset, phenotype and biochemical diagnostic criteria. Not surprisingly, the focus is predominantly on diagnosing type I and type 2 diabetes. More challenging for the physician is to think of monogenic diabetes, which results from gene mutations that reduce beta cell function. Often misdiagnosed as type I or type 2 diabetes, maturity-onset diabetes of the young (MODY) is the most common form of monogenic diabetes, accounting for $\mathrm{I}-2 \%$ of all diabetes cases. A diagnosis of monogenic diabetes has important implications in treatment, the prediction of disease progression and screening of family members. We highlight two cases of monogenic diabetes, where the diagnosis had significant implications in all the above parameters. This is followed by a discussion on the glucokinase and hepatocyte nuclear factor-I alpha MODY, which together constitute the most frequent cause of MODY syndromes in all populations.
\end{abstract}

Correspondence to K Swaminathan, Department of Diabetes, Victoria Hospital, Kirkcaldy KY2 5AH, UK
tel. +44 (0) I592 643355 ext. I582 e-mail

krishnan.swaminathan@nhs.net

KEYWORDS Diabetes, maturity-onset diabetes of the young, molecular genetics

DECLARATION OF INTERESTS No conflict of interests declared.

The diagnosis of diabetes is routinely thought of as a straightforward differentiation between type I and type 2 diabetes, based on various phenotypic and biochemical characteristics. Clinicians should be aware of monogenic diabetes that results from the inheritance of mutations in a single gene. These syndromes have specific characteristics that should alert the physician to request blood tests for molecular genetics, as a diagnosis of monogenic diabetes has important therapeutic implications, as outlined in the cases below.

\section{CASE I}

A 38-year-old man with a previous diagnosis of type I diabetes and poor glycaemic control was seen in the diabetes clinic for an annual follow-up. A review of the history and the patient's case notes revealed a strong family history of type $I$ and 2 diabetes in different generations. The patient was diagnosed with type I diabetes at 15 years of age, based on classical osmotic symptoms, glycosuria and random blood glucose of $18 \mathrm{mmol} / \mathrm{l}$ with no ketosis. Insulin treatment had been initiated at diagnosis and, over the years, his glycaemic control was poor and he had developed sight-threatening retinopathy needing laser treatment and overt diabetic nephropathy with an albumin-creatinine ratio of $122 \mathrm{mg} / \mathrm{mmol}$.

The patient's reluctance to take insulin regularly and frequent non-attendance at the clinics was cited as reasons for his poor glycaemic control. Anti-glutamic acid antibodies (GAD) were negative. In view of the family history, hepatocyte nuclear factor-I alpha (HNF$\mathrm{I} \alpha$ ) maturity-onset diabetes of the young (MODY) was considered. Molecular genetic analysis showed a

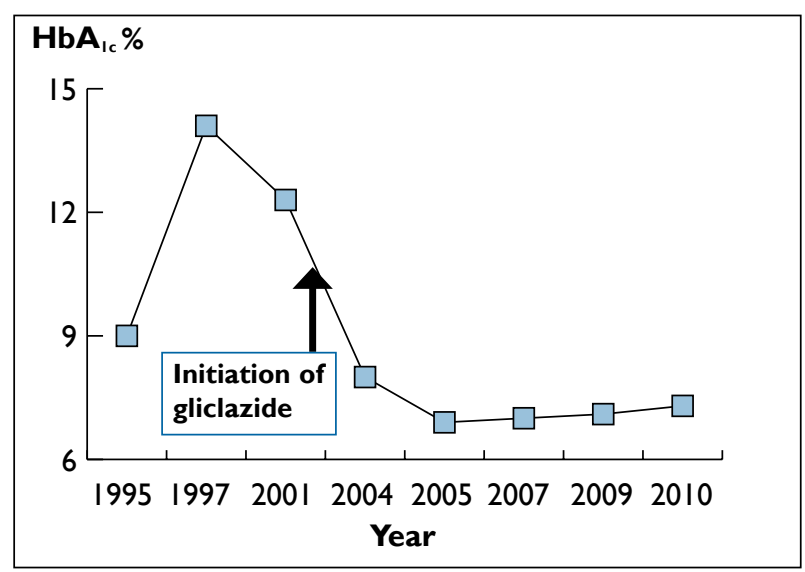

FIGURE I Dramatic and sustained improvement of glycaemic control after initiation of low-dose gliclazide (arrow).

missense mutation SI45L in exon 2 of HNF-I $\alpha$ gene. In view of known sensitivity of HNF-I $\alpha$ MODY patients to sulphonylureas, insulin was discontinued and a therapeutic trial of low-dose gliclazide, $40 \mathrm{mg}$ twice daily, initiated. A dramatic improvement in glycosylated haemoglobin was observed (Figure I), which was maintained in a subsequent clinic review.

\section{CASE 2}

A 39-year-old resuscitation officer with a body mass index of 26 self-presented with a high capillary blood glucose level. The patient reported that her mother, two maternal uncles and maternal grandfather were diagnosed with 'diet-controlled type 2 diabetes'. A fasting plasma glucose was $7.3 \mathrm{mmol} / \mathrm{l}$ with a glycosylated haemoglobin $\left(\mathrm{HbA}_{\mathrm{Ic}}\right)$ level of $6 \%$. An oral glucose tolerance test showed a fasting glucose of $6.5 \mathrm{mmol} / \mathrm{l}$ and a two-hour 
value of $7.3 \mathrm{mmol} / \mathrm{l}$. The patient was negative for GAD, a marker for type I diabetes. Molecular genetic testing in view of the above features showed her to be heterozygous for a missense mutation S340I in exon 8 of the glucokinase (GCK) gene. This results in a substitution of amino acid isoleucine for serine at codon 340 , consistent with a diagnosis of MODY, subtype glucokinase. The patient continues to do well on no medications for diabetes and she is followed up annually for glycaemic control and microvascular complications.

\section{DISCUSSION}

In 1974, Tattersall described three families with dominantly inherited diabetes, who could be treated with sulphonylureas after 40 years of diagnosis.' In the same year, Tattersall and Fajans coined the acronym MODY, which was defined as 'fasting hyperglycaemia diagnosed under age 25 years which could be treated without insulin for more than two years'.

Maturity-onset diabetes of the young describes a clinically heterogenous group of dominantly inherited disorders with onset usually before 25 years of age, presenting as non-ketotic diabetes mellitus, due to mutations in genes that result in defective beta cell function. The mutations affect genes encoding GCK, a rate-limiting glycolytic enzyme, or those that encode five other transcription factors, of which HNF-I $\alpha$ and HNF$4 \alpha$ are the most relevant to everyday clinical practice. Monogenic diabetes caused by such mutations accounts for approximately $\mathrm{I}-2 \%$ of all diabetes cases. ${ }^{2}$

Mutations in GCK and HNF-I $\alpha$ are the most common causes of monogenic diabetes. ${ }^{3}$ There are certain features in the history and biochemistry that should alert the physician to the possibility of monogenic diabetes (Table I). With GCK mutations, the predominant feature is the presence of persistent fasting hyperglycaemia $(5.5-8 \mathrm{mmol} / \mathrm{l})$ that is stable for months or years. ${ }^{4}$ Glucokinase catalyses the first rate-limiting step of glycolysis and determines the rate of adenosine triphosphate (ATP) production in response to the blood glucose concentration. Mutations in the GCK gene reduce the efficiency of the pancreatic beta cell to use glucose for ATP production, thereby leading to higher than normal blood glucose to trigger insulin release. An oral glucose tolerance test (OGTT) in such patients typically shows, as in Case 2, a small increment in the two-hour glucose, usually less than $3 \mathrm{mmol} / /^{4}$ and an $\mathrm{HbA}_{\mathrm{Ic}}$ that rarely exceeds $7.5 \%$. A diagnosis of GCK MODY in our patient had important implications for her prognosis and treatment. Patients with such mutations rarely suffer from microvascular complications and treatment with oral agents or insulin rarely affects $\mathrm{HbA}_{\mathrm{lc}}{ }^{5}$

Mutations in HNF-I $\alpha$ gene are the most common form of MODY syndromes. ${ }^{3}$ Physicians should have a high
TABLE I Clinical and biochemical features that aid in the diagnosis of monogenic diabetes*

\begin{tabular}{|l|l|l|}
\hline $\begin{array}{l}\text { Mutation } \\
\text { type }\end{array}$ & $\begin{array}{l}\text { Clinical and biochemical } \\
\text { features }\end{array}$ & $\begin{array}{l}\text { Chromosome } \\
\text { locus }\end{array}$ \\
\hline $\begin{array}{l}\text { Glucokinase } \\
\text { mutation } \\
\text { (MODY 2) }\end{array}$ & $\begin{array}{l}\text { Mild fasting hyperglycaemia } \\
\text { with a small increment in } \\
\text { the two-hour glucose on an } \\
\text { oral glucose tolerance test, } \\
\text { low risk of microvascular } \\
\text { complications, usually do } \\
\text { not need treatment }\end{array}$ & $7 \mathrm{p} / 3$ \\
\hline $\begin{array}{l}\text { HNF-I } \alpha \\
\text { mutation } \\
\text { (MODY 3) }\end{array}$ & $\begin{array}{l}\text { Age of onset less than 25 } \\
\text { years, strong family history of } \\
\text { type I and type 2 diabetes, } \\
\text { low renal threshold for } \\
\text { glycosuria, large increment in } \\
\text { two-hour glucose, sensitive to } \\
\text { sulphonylureas }\end{array}$ & $\mid$ I2q24.3I \\
\hline $\begin{array}{l}\text { HNF-4 } \alpha \\
\text { mutation } \\
(\text { MODY I) }\end{array}$ & $\begin{array}{l}\text { Similar to HNF-I } \alpha \text { but } \\
\text { renal threshold not low, age } \\
\text { at diagnosis may be later, } \\
\text { sensitive to sulphonylureas }\end{array}$ & $20 \mathrm{q} \mid 3.12$ \\
\hline $\begin{array}{l}\text { HNF-I } \beta \\
\text { mutation } \\
(\text { MODY 5) }\end{array}$ & $\begin{array}{l}\text { Pancreatic atrophy, insulin- } \\
\text { requiring diabetes, renal } \\
\text { abnormalities at birth or } \\
\text { infancy, hyperuricaemia, } \\
\text { abnormal liver function, } \\
\text { genital malformations }\end{array}$ & I7qI2 \\
\hline
\end{tabular}

* Not a complete list.

index of suspicion if the patient presents with diabetes at less than 25 years of age, has a strong family history of both type I and type 2 diabetes and has a greater than $5 \mathrm{mmol} / \mathrm{l}$ increment on the two-hour glucose value on an OGTT, ${ }^{4}$ a low renal threshold ${ }^{6}$ with glycosuria at blood glucose values less than $10 \mathrm{mmol} / \mathrm{l}$ and a marked sensitivity to sulphonylureas. ${ }^{7.8}$

Hepatocyte nuclear factors (HNF-I $\alpha, H N F-4 \alpha$ and HNF-I $\alpha$ ) are a network of transcription factors that regulate insulin gene expression ${ }^{9.10}$ and therefore insulin secretion. Unlike GCK mutations, the hyperglycaemia in HNF-I $\alpha$ mutation tends to worsen with time and patients may develop the full spectrum of complications, as in case I. Patients with HNF-I $\alpha$ MODY, even those with a long duration of diabetes as in our case, respond dramatically to sulphonylureas ${ }^{8}$ and this should therefore be considered as the initial treatment of choice. The reason for the sulphonylurea sensitivity may relate to the fact that the beta cell defect in HNF-I $\alpha$ MODY is upstream of the sulphonylurea receptor with a preservation of the signalling pathway downstream of the receptor.7 A prompt diagnosis in our patient (case I) and an early institution of sulphonlyurea therapy might have prevented, or at least delayed, the development of sight-threatening retinopathy and overt diabetic nephropathy. 


\section{CONCLUSION}

Clinicians should have a high index of suspicion for monogenic diabetes in the appropriate clinical setting as its diagnosis can predict clinical course, appropriate treatment, help in genetic counselling and explain associated abnormalities.

\section{REFERENCES}

I Tattersall RB. Mild familial diabetes with dominant inheritance. $Q$ J Med 1974; 43:339-57.

2 Frayling TM, Bulman MP, Ellard S et al. Mutations in the hepatocyte nuclear factor-I alpha gene are a common cause of maturity onset diabetes of the young in the UK. Diabetes 1997; 46:720-5 doi: $10.2337 /$ diabetes. 46.4 .720

3 Ellard S, Bellanné-Chantelot C, Hattersley AT; European Molecular Genetics Quality Network (EMQN) MODY group. Best practice guidelines for the molecular genetic diagnosis of maturity-onset diabetes of the young. Diabetologia 2008; 51:546-53. doi:10.1007/ s00 I25-008-0942-y

4 Stride A,Vaxillaire M, Tuomi T et al. The genetic abnormality in the beta cell determines the response to an oral glucose load. Diabetologia 2002; 45:427-35. doi: 10.1007/s00 I25-00I-0770-9

5 Murphy R, Ellard S, Hattersley AT. Clinical implications of a molecular genetic classification of monogenic beta-cell diabetes. Nat Clin Practice 2008: 4:200-13. doi: I0.1038/ncpendmet0778

6 Menzel R, Kaisaki PJ, Rjasanowski I et al.A low renal threshold for glucose in diabetic patients with a mutation in the hepatocyte nuclear factor-lalpha (HNF-lalpha) gene. Diabet Med 1998; I5:8|6-20.doi: I0.1002/(SICl) I096-9|36(I998I0) I5:10<8|6::AIDDIA7I4>3.0.CO;2-P
Acknowledgments The authors are grateful to Professor AT Hattersley and Professor S Ellard, Peninsula Medical School, Exeter, for their specialist expertise and help with molecular genetic analysis.

7 Pearson ER, Starkey BJ, Powell RJ et al. Genetic cause of hyperglycaemia and response to treatment in diabetes. Lancet 2003; 362:1275-8I. doi: I0.1016/S0|40-6736(03) |457|-0

8 Pearson ER, Liddell WG, Shepherd $M$ et al. Sensitivity to sulphonylureas in the patients with hepatocyte nuclear factorlalpha gene mutations: evidence for pharmacogenetics in diabetes. Diabet Med 2000; 17:543-5. doi:10.1046/j.1464-549|.2000.00305.x

9 Stoffel M, Duncan SA. The maturity-onset diabetes of the young (MODYI) transcription factor HNF4 (alpha) regulates expression of genes required for glucose transport and metabolism. Proc Natl Acad Sci U S A 1997; 94:13209-14. doi:10.1073/pnas.94.24.13209

10 Fajans SS, Bell GI, Polonsky KS. Molecular mechanisms and clinical pathophysiology of maturity-onset diabetes of the young. N Engl J Med 200I; 345:97I-80. doi: I0.1056/NEJMra002I68

\section{UPCOMING SYMPOSIA}

Stockton symposium: Recent advances in medicine 30 June

\begin{tabular}{|rr}
\hline Dermatology & 21 September \\
\hline Paediatrics (RCPE/RCPCH joint symposium) & 29 September \\
\hline Diabetes & 7 October \\
\hline Renal Medicine & 13 October \\
\hline Trainees \& Members' Committee symposium & 28 October \\
\hline Preston symposium & 9 November \\
\hline Neurology (RCPE/RCGP joint symposium) & 16 November \\
\hline Cardiology & 25 November \\
\hline $\begin{array}{l}\text { 5 Ist St Andrew's Day Festival Symposium: } \\
\text { Update on Acute Medicine }\end{array}$ & I-2 December \\
\hline \multicolumn{2}{|c|}{ Book online at http://events.rcpe.aC.uk } \\
\hline
\end{tabular}

All symposia are held at the Royal College of Physicians of Edinburgh unless otherwise stated. Further symposia may be added at a later date.

Programme details at: http://events.rcpe.ac.uk or contact the Symposium Co-ordinator: Tel: 0I3I 2257324

Email: e.strawn@rcpe.ac.uk

\section{Webstreamed lectures}

If you are unable to attend symposia at the College in Edinburgh, selected lectures from all symposia are available to view and listen to in the Online Education section of the secure area of the College website. There are currently more than 100 lectures covering all the medical specialties and a range of generic topics. 